Patriarchal Attitudes 


\title{
Patriarchal Attitudes
}

\section{Women in Society}

\author{
by \\ EVA FIGES
}

With a new introduction

by the author

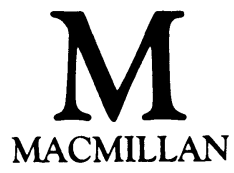


() Eva Figes 1970, 1978, 1986

Softcover reprint of the hardcover 1st edition 1986 978-0-333-41706-5

All rights reserved. No reproduction, copy or transmission of this publication may be made without written permission.

No paragraph of this publication may be reproduced, copied or transmitted save with written permission or in accordance with the provisions of the Copyright Act 1956 (as amended).

Any person who does any unauthorised act in relation to this publication may be liable to criminal prosecution and civil claims for damages.

First published 1970 by Faber and Faber Limited, and by Virago Limited in 1978

First published by Macmillan Education Ltd 1986

Published by

MACMILLAN EDUCATION LTD

Houndmills, Basingstoke, Hampshire RG21 2XS

and London

Companies and representatives

throughout the world

ISBN 978-0-333-41707-2

ISBN 978-1-349-18207-7 (eBook)

DOI 10.1007/978-1-349-18207-7 


\section{Contents}

Introduction

page 6

To begin with ... 10

I. A Man's World 17

II. A Man's God 35

III. Mammon 66

IV. Rousseau, Revolution, Romanticism and Retrogression 92

V. Mind over Matter 111

VI. Learning to be a Woman 135

VII. A Woman's World 152

VIII. Today and Tomorrow 168

Appendix 186

Acknowledgements $\quad 187$

Bibliography 188

Index 189 